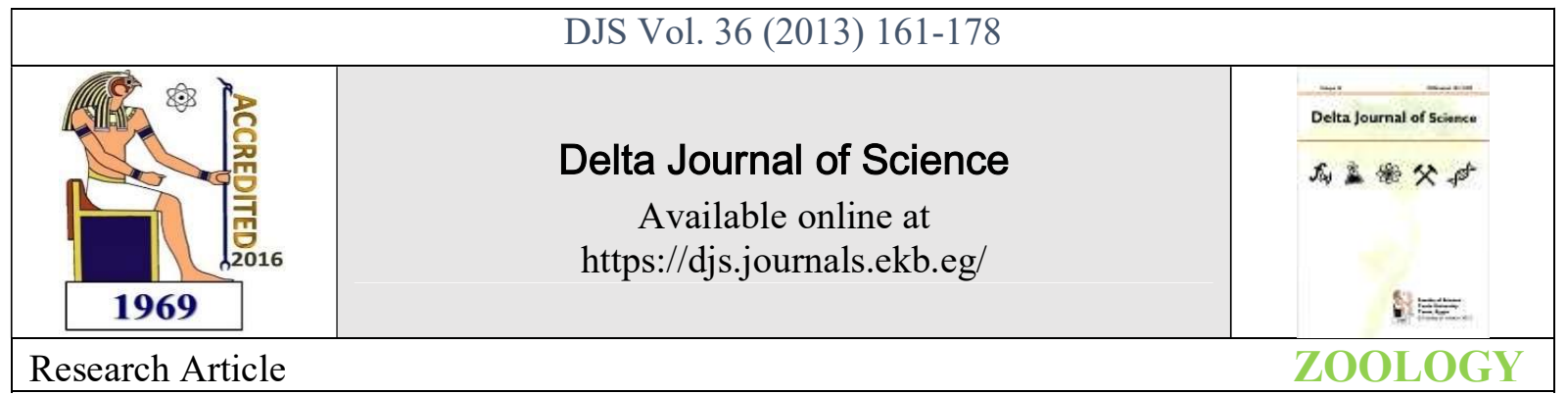

\title{
Effect of Some New Aza - Uracil Derivatives in Treatment of Schistosoma mansoni Infection
}

\author{
Afrah F. Salama ${ }^{1 *}$, Ahmed A. El-Barbary ${ }^{2}$, Ismail M. Al-Sharkawi ${ }^{3}$ and Yara A. Helal ${ }^{1}$ \\ Chemistry Department, ${ }^{1}$ Biochemistry, ${ }^{2}$ Organic Chemistry Section,.${ }^{3}$ Zoology Department, \\ Faculty of Science- Tanta University, Egypt.
}

Corresponding author.

Afrah Fatthi Salama, Ph.D. Faculty of Science, Tanta University, Egypt, Post number. 31527

Mobile. +2-018-105-82-84, Telefax.+2-040-33-50-804, E-mail. afrahsalama@yahoo.com

\begin{abstract}
Praziquantel is now the drug of choice for treatment of schistosomiasis, its use in the control of schistosomiasis at a population level faces some problems, and thus a search for new drugs with antischistosomal activity is urgently needed. In the present study we worked on newly synthesized 1, 2, 4-triazine derivative compounds. The study was carried out on 190 female mice for the assessment of the antischistosomal activity of 1,2,4-triazine compounds, with special reference to histopathological examination and some liver tissues biochemical parameters. The results showed four compounds 3, 6, 7 and 10 caused suppressive effect on the development of granuloma reaction as compared with Schistosoma infected only. Compound 10 had the highest effect in reducing worm burden lesser sever enzymatic dysfunction. Some compounds caused a marked improvement in almost enzymatic activity particularly 5'nucleotidase, G6P, Na-K ATPase and Mg-ATPase activities. ALT and AST activities decreased than the normal. Also, some compounds showed improvement in catalase and GST enzyme activities indicating their antioxidant effect. Some compounds as 9 and 10 showed antischistosomal activity; also compounds 3, 6 and 10 had anti-inflammatory activity.
\end{abstract}

Keywords. Schistosomiasis, Shistosoma mansoni, Chemotherapy, PZQ, 1, 2, 4-triazine, Oxidative stress

\section{INTRODUCTION}

Schistosomiasis is a chronic parasitic disease caused by trematode blood fluke of the genus Shistosoma which is considered the second most important parasitic infection after malaria in terms of public health and economic impact. The infection may occur by one of the species $S$. hematobium, $S$. mansoni, S. japonicum (Larotski 1981). Adult Shistosoma mansoni parasites live within the portal vasculature, where female worms lay eggs that are intended for transmission across the intestinal wall into the gut lumen and from to the outside of the host. However, because blood flow in the portal system is towards the liver, many of the eggs are carried to that organ where they become lodged in the sinusoids. In the liver, the initial pathological response to eggs is an immunologic reaction to antigens secreted by the organism inside the eggs, and this response appears as a granulomatous reaction Warren (1979). In addition, the host reaction to the eggs led to an extensive damage of the hepato portal vascular system and subsequent fibrous scar formation, according to these results, the liver weight was increased Warren (1972). However, hepatic involvement is considered the most serious complication of the infection because schistosomes live in the portal circulation and some ova are occasionally swept back to the liver inducing granulomatous reactions Saleh (1979).

In the control of schistosomiasis, praziquantel is the drug of choice because it is more effective than oxamniquine, especially for the treatment of mansoniasis. Drug resistance to praziquantel has been demonstrated, thus, a search for new drugs with anti-schistosomal activity is urgently needed. 
Owing to mentioned above, the present study used some novel hetero bicyclic derivatives bearing the 1,2,4-triazine moiety, where the 1,2,4-triazine ring is a prominent structural core system found in numerous biologically active compounds and displayed an impressive array of biological activities, among which anti-tumor Walters et al., (1972), antiviral Falke and Rada (1970) and antifungal Matolcsy (1966). To achieve a new drug with possible antischistosomal activity and antiinflammatory effect, it is of interest in the present study to evaluate the biological activity of newly synthesized 1,2,4triazine derivatives against $S$. mansoni infection via the investigation of some biochemical parameters throughout the infection period.

\section{2- Materials and methods}

\section{1 - Compounds under investigation and Chemicals}

Sixteen derivatives of 1,2,4-triazine compounds were prepared in Chemistry Department, Faculty of Science, Tanta University, Tanta, Egypt in collaboration with Chemistry Department at Southern Denmark University, Odense, Denmark and developed as a part of the joint project entitled "Drug Discovery for Hepatitis, HIV, and Schistosomiasis" and funded by DANIDA (Danish International Development Agency). The nomenclature of the compounds is illustrated in Table (1). Tris (hydroxyl methyl) amino methane, adenosine5 -monophosphoric acid disodium salt , ascorbic acid, malic acid, adenosine triphosphate sodium salt from (Sigma Chemical Co., USA), 1,1,3,3-tetramethoxypropane (Fluka Chemical Company) , Glutathione, 5, 5' -dithio-bis-2nitrobenzoic acid, 1-chloro-2, 4-dinitrobenzene, thiobarbituric acid were purchased from Sigma Chemical Co. (St. Louis, MO, USA). All other chemicals used in the experiment were of analytical grade.

\section{2 - Parasite and experimental animals}

Shistosoma mansoni cercariae were obtained from laboratoryinfected Biomphalaria alexandrina snails supplied by the Schistosome Biological Supply Program, Theodore Bilharz Research Institute at Warrak El-Hadar, Imbaba, Cairo, Egypt. The cercariae were collected from the infected snails according to the method described by Christensen et al. (1984). Female Swiss albino mice, weighing 20-25 g (age 6 weeks) were used as the experimental animals throughout the study. Mice were obtained from Schistosome Biological Supply Program Theodore Bilharz Research Institute. The animals were maintained as performed by the national guidelines and protocols approved by the Institutional Animal Ethics Committee on laboratory standard balanced diet and free access to water, and were let for about one week before experimentation to adapt the laboratory conditions.

Mice were individually infected with 70-80 freshly shed cercariae according to the technique of Christensen et al. (1984).

\section{3- Evaluation of the tolerance of $(1,2,4$ - triazine) derivatives by $S$. mansoni-infected mice.}

Preliminary evaluation of the tolerance of the sixteen 1,2,4triazine derivatives under investigation started at one dose of $600 \mathrm{mg} / \mathrm{kg}$ body weight as compared with the curative dose of Praziquantel (the reference anti-schistosomal drug). Results of that treatment showed that all the animals died after 24 hours from receiving the $600 \mathrm{mg} / \mathrm{kg}$ body weight dose. Then the treatment with the sixteen 1,2, 4-triazine derivatives was repeated at a lower dose of $500 \mathrm{mg} / \mathrm{kg}$ body weight as one dose, after 24 hours, these derivatives didn't show any objective toxicity as monitored by the observation of the death rate at that dose level for all compounds except compounds 1,7 and 9 , caused a death rate of $60 \%, 50 \%$ and $50 \%$, respectively. Accordingly, the chosen dose of the treatment for these three compounds was $300 \mathrm{mg} / \mathrm{kg}$ body weight that caused a marked reduction in the death rate.

\section{4- Animal grouping and treatment}

One hundred and ninety female mice were used in the study, these mice were divided into 19 groups, 10 mice each, 18 groups were infected with S. mansoni, by immersion of tails into suspension of 70-80 freshly shed cercariae for 60 minutes (Cercariae were obtained from the Biomphalaria alexandrina snails within one hour after shedding, Christensen et al., (1984). From the 18 animal groups, 16 groups were administered the sixteen compounds orally at $1 \times 500 \mathrm{mg} / \mathrm{kg}$ body weight/ day for two successive days according to evaluation of their tolerance as maintained above. The seventeenth group was administered praziquantel, the reference anti-schistosomal drug, orally at $1 \times 600 \mathrm{mg} / \mathrm{kg}$ body weight as one dose. The eighteenth group was administered $0.2 \mathrm{ml} / \mathrm{mice}$ of DMSO (vehicle) taken as bilharzial control i.e. infected with S. mansoni and left without treatment. The last group, 19th was not infected with S. mansoni and taken as a normal control. After infection cercariae develops into schistosomula, then progress into adult worms in about 30 days. Administration of the treatments started at the 36th day from beginning of the infection, as all the stages of egg formation are present. Anti-schistosomal activity was evaluated on day 17 from the beginning of the treatment.

2.5- Parasitological Estimations. At the end of the experimental period, mice were euthanized, liver was removed, washed in saline solution, blotted with filter paper and weighted. Anti-schistosomal activity was evaluated by measuring the parasitological parameters including enumeration of the worm burden as described by Christensen et al. (1984), Oogram pattern, egg count according to Pellegrino et al.,(1962) Andrade and warren (1964) and the change in granuloma size according to the method of Cheever et al., (1983).

2.6 - Liver sampling . Part of the liver was homogenized using homogenizer with Teflon pestle in phosphate buffer $\mathrm{pH} 7.4$ and kept at $-20 \mathrm{oC}$, tell estimation of the biochemical parameters. Another portion of the liver was fixed in $10 \%$ buffered formalin for histopathological analysis.

\section{7- Histopathological analysis}

The standard protocol of tissue staining by hematoxyline and eosin (Bancroft and stevens, 1975) was applied and slides were examined.

\section{8 - Biochemical Assays}

Glutathione-S-transferase was assayed on tissue homogenate according to Habig et al., (1974) Catalase according to Xu et al., (1997), 5 '-nucleotidase according to (EL-Aaser and ELMerzaban (1975).Glucose-6-phosphatase), Aminotransferase and adenosine triphosphatase were estimated according to Swanson (1950), Reitman and Frankel (1957) and (Bonting et al., 1961) respectively. Malondialdehyde (MDA) was estimated according to Mesbah et al., (2004). Total thiol concentration was estimated according to Sedlak and Lindsay (1968). Total protein was estimated according to Lowry et al., (1951). Total lipid was estimated according to Frings et al., (1972). 


\section{9- Statistical Analysis}

Results were analyzed by the Graph Pad in Stat Software, One-way analysis of variance, ANOVA to assess the significant differences among the treated groups. The Dunnett Test was used to compare all groups versus the non-infected control group. The criterion for statistical significance was set at $\mathrm{P}<0.05$ or $\mathrm{P}<0.01$.

\section{RESULTS}

The relative liver weights ( $\mathrm{g} / 100 \mathrm{~g}$ body weight) of noninfected, bilharzial infected only, bilharzial infected and treated with praziquantel and bilharzial infected and treated with $(1,2,4)$ triazine derivative compounds mice are summarized in Ttable (2). Bilharzial infection only showed a progressive increase in the relative liver weight to $57.6 \%$ relative to the normal (non-infected animals) during the infection period (6 weeks post-infection). Also, treatment of bilharzial-infected mice with praziquantel and triazine derivatives caused progressive significant increase in relative liver weight compared to the non-infected animals $(\mathrm{P}<0.01)$.

Table(3) demonstrates the activities of $5^{\prime}-\mathrm{NT}, \mathrm{G}-6-\mathrm{p}, \mathrm{Na}^{+}-\mathrm{K}^{+}$ and $\mathrm{Mg}^{2+}$ - ATPases enzymes. 5'-NT enzyme was significantly decreased $(\mathrm{P}<0.05)$ in infected and non-treated animals, and in animals infected with Schistosoma and treated with compounds 1, 2 and 9. Also, animals infected with Schistosoma and treated with compounds 3,10 and 13 showed a significant decrease $(\mathrm{P}<0.01)$ in $5^{\prime}$-NT enzyme activity when compared with that of non-infected animals (group 1) while, other groups were insignificantly changed from normal animals relative to $5^{\prime}-\mathrm{NT}$ enzyme $(\mathrm{P}>0.05)$. G-6$\mathrm{p}, \mathrm{Na}^{+}-\mathrm{K}^{+}$ATPases and $\mathrm{Mg}^{2+}$-ATPases enzyme activity showed insignificant changes in all groups when compared with the non-infected normal animals and insignificant increase in those infected and treated with the compound 5 $(\mathrm{P}>0.05)$. As shown in Table (3).

ALT enzyme activity was significantly decreased $(\mathrm{P}<0.01)$ in infected and non-treated animals, in those infected and treated with compounds $1,2,4,5,6,7,8,9,13,14,15$ and 16 when compared to the normal non-infected group (Table 3). While, animals infected with Schistosoma and treated with PZQ, treated with triazine derivatives as, compounds $3,10,11$ and 12 were insignificantly decreased from that of the normal noninfected animals $(\mathrm{P}>0.05)$.

AST enzyme activity was significantly decreased in all groups either infected with shistosoma only or infected and treated with PZQ or 1, 2, 4-triazine derivatives when compared with the normal non-infected animals $(\mathrm{P}<0.01)$ (Table 3$)$.

Catalase enzyme activity Table (4) showed a significant increase $(\mathrm{P}<0.05)$ in mice infected with Schistosoma and treated with compounds 2 and 4 , also there was a highly significant increase in catalase $(\mathrm{P}<0.01)$ in groups treated with compounds $3,6,7,12$ and 14 when compared with group 1 (non- infected animals). On the other hand, a significant decrease was observed in groups treated with compounds 11 and 13 while a highly significant decrease $(\mathrm{P}<0.01)$ in the catalase enzyme activity was also seen in group 2 (infected with Schistosoma and not treated) and groups treated with compounds $1,5,8,13$ and 15 when compared with group 1 (normal non- infected animals). In addition, mice infected with Schistosoma and treated with PZQ showed insignificant decrease $(\mathrm{P}>0.05)$ in catalase enzyme activity, while mice infected with Schistosoma and treated with compounds 9, 10 and 16 showed insignificant increase when compared with the control (Table 4).

GST enzyme activity was significantly increased $(\mathrm{P}<0.01)$ in Schistosomal infected animals and treated with PZQ, compounds $1,2,3,4,5,7,10$ and 11 when compared to the normal animals ( group 1). On the other hand, bilharzial animals infected only (group 2) infected animals and treated with the compounds 6 and 9 showed an insignificant increase in GST activity when compared with the normal $(\mathrm{P}>0.05)$, while those treated with the compounds $8,12,14,15$ and 16 showed an insignificant decrease in GST enzyme activity when compared to the normal animals $(\mathrm{P}>0.05)$ (Table 4).

Oxidative stress marker, Lipid peroxidation products (MDA) of the liver of non-treated infected animals only and those infected with Schistosoma and treated either with PZQ or with the sixteen 1,2, 4-triazine-derivatives, showed a significant increase $(\mathrm{P}<0.01)$ when compared with that of the normal non-infected animals, (Table 4).

Total thiol (Table 4) revealed a significant decrease $(\mathrm{P}<0.05)$ in Schistosomal infected animals only (group 2) and animals infected with Schistosoma and treated with the compound 4 when compared with the normal group 1 (non-infected animals). Also, animals infected and treated with the triazinederivatives $1,2,8,12,13,14,15$ and 16 showed a strong reduction in liver total thiol $(\mathrm{P}<0.01)$ when compared to the normal animals (group 1). Animals infected and treated with PZQ or triazine-derivatives like $3,5,6,7,9,10$ and 11 showed an insignificant decrease in liver total thiol concentration $(\mathrm{P}>0.05)$ when compared with that of the normal control.

Total liver protein content which considered as a marker of tissue injury and a rewound healing on treatment (Table 4) showed a significant decrease $(\mathrm{P}<0.01)$ in Schistosomal infected only and in the rest of all groups either treated with PZQ or with the triazine-derivatives, except animals treated with the compound (1) that was insignificantly changed from that of the control group $1(\mathrm{P}>0.05)$.

On the other hand, liver total lipids showed a strong increase $(\mathrm{P}<0.01)$ in infected mice and those treated with triazinederivatives as compound $4,5,10,12,13$ and 16 when compared with control. Also, infected animals and treated with triazine derivatives 6 and 7 revealed a significant increase in liver total lipids $(\mathrm{P}<0.05)$ when compared with the normal (non-infected animals). Liver total lipids of animals infected with Schistosoma and treated with PZQ, triazine derivatives as $1,2,3,8,9,11,14$ and 15 were insignificantly increased from those of the control $(\mathrm{P}>0.05)$, (Table 4).

Treatment of $S$. mansoni-infected mice with 1,2,4 triazine derivatives showed that most of triazine derivative compounds did not cause any appreciable reduction in worm burden and liver egg count when compared with the $S$. mansoni infected mice, while mice treated with compounds 4 and 5 showed a significant increase $(35.26 \%)$ and $(54.58 \%)$, in the worm burden as compared to the infected animals and PZQ group (Table 5) this increscent may be due to that, these two compounds have an effect on the fertility of the worm and so increased the number of worms. Only a significant reduction $(27.53 \%)$ in worm burden was observed in mice treated with compound 9 at a dose of $300 \mathrm{mg} / \mathrm{kg}$ x 2days as compared with Praziquantel (the reference anti-schistosomal drug) which cause a significant reduction $(85.26 \%)$ at a dose of 600 $\mathrm{mg} / \mathrm{kg} \times 1$ day in the worm burden at $(\mathrm{P}<0.05)$.

The oogram changes caused by administration of 1,2,4triazine derivatives revealed that, compounds as , 3, 6, and 10 showed the deviation of the oogram picture from the control, where there was no any viable egg of mature stage, 
almost eggs were small unfertilized. Compounds 3 and 10 were found to produce an increase in the percentage of first stage of eggs followed by decrease in the second stage eggs as compared to the infected control group. Also, worms were very slow in motion, and some of them were dead. Disappearance of the first stage that was followed by successful disappearance of immature eggs of the following stages and hepatic shift was observed in mice treated with compound 6 also more than $90 \%$ from the examined eggs were unfertilized in the same group.

Administration of the sixteen 1,2,4-triazine compounds at two doses 24 hours a part at the maximum tolerable dose to the Schistosoma infected animals showed that, four compounds caused suppressive effect on the development of granuloma reaction as compared with the Schistosoma infected liver sections. Compound 10 had the highest reduction percent of $99.2 \%$ followed by compounds 3,6 and 7 , with reduction percent of $98.8 \%, 98.5 \%$ and $97.6 \%$, respectively. While reduction of $88.3 \%$ was recorded for mice administered with Praziquantel (Table 6).

Histopathological examination of mice liver tissues of the different studied groups showed the following changes.

Normal (non-infected group): normal liver cells (hepatocytes) radiating from a central vein with normal hepatic strands (fig. 1a) Schistosoma infected group without treatment shows that $S$. mansoni-infection resulted in formation of granulomas around the viable-egg of Schistosoma and numerous eosinophils as an inflammatory reaction. Schistosomal pigments appeared as well as dark granules in the Kupffer cells. Examination of the gross pigment loaded cells had diffuse distribution through the liver, but their concentrations are higher in periportal infiltrate and in periovular granulomas. On the other hand, the granulomatous reaction is collagenized and forms of histocytes, lymphocytes, eosinophils and fibroblasts (fig. 1b).

$P Z Q$ group: Liver sections of bilharzial infected animals and treated with Praziquantel (PZQ) show a reduction in granuloma area compared to bilharzial infected mice only and non-viable Schistosome eggs with inflammatory cell consists mainly of lymphocytes and eosinophils. Also, congested RBCS inside hepatocyte are observed (fig. 1c).

Schistosomal infected animals and treated with compound 10 shows the most suppressive effect on the development of granulomatous reaction as compared with bilharzial only. Infected liver sections treated with compound 10 have the highest reduction percent $(99.2 \%)$ and reduced granulomas area to $0.26 \mathrm{~mm}^{3}$ as compared to the bilharzial infected animals only. Also, inflammatory cell infiltrations in liver and around the egg of Schistosoma are not commonly found (fig. 1d).

\section{Discussion}

The search for broad-spectrum, effective non-toxic and inexpensive antibilharzial drugs for schistosomes' treatment in the developing countries is of great interest. In addition, an effective specific drugs in the management of schistosomiasis transmission to avoid the possibility of development of drugresistant strain of the parasite. For the screening of the drugs, several criteria for the assessment of drug activity were used by Pellegrino et al. (1962).

The relative liver weights of all groups (either infected with Schistosoma only or infected and treated with the PZQ and the sixteen compounds) were increased when compared with those of the normal (non-infected group 1). These results are compatible with those of previous work of many authors. Rizk et al., (2006) explained the increased liver weight and reduction in body weight gain owing to schistosomal infection is due to the presence of the developing worms and the initiation of egg deposition and also due to several metabolites released by the parasite which affect the host hepatic tissues. In schistosomiasis, the liver eggs load is known to account for the extent and the degree of hepatic derangement at physiological (Tanabe et al., 1989) and histopathological levels (Hirsch et al., 1997).

It was of interest in the present study to investigate the levels of some enzymes namely (5'-nucleotidase, glucose-6phosphatse, ATPases, Transaminases, Catalase and GST) and total protein, total lipid, total thiol and MDA in liver tissues of mice infected with $S$. mansoni to reflect changes that occur in the liver in the early phases of disease progression.

Treatment with 1, 2, 4-triazine derivative compounds caused less sever liver enzymatic dysfunction, and a marked improvement in 5'- nucleotidase activity. The improvement in 5'-NT was for the compounds 4, 5, 6, 7, 11, 12, 15 and 16 treatments were much pronounced than that caused by PZQ, the 5'-NT values were found to be within the range of normal healthy mice and improved as compared with bilharzial control. Liver enzymatic activities particularly $\mathrm{Na}^{+}-\mathrm{K}^{+}$ ATPase, $\mathrm{Mg}^{2+}$ ATPase and G-6-P did not showed insignificant decrease in their activities as compared with normal healthy mice and these results were nearly in agreement with that recorded by Shaheen and Ebeid (1992), who found that $S$. mansoni infection caused a moderate decrease of brain $\mathrm{Na}^{+}-\mathrm{K}^{+}$ ATPase with a marked inhibition of its $\mathrm{Mg}^{2+}$ - stimulated ATPase, meanwhile, a marked inhibition in both renal ATPase activities were observed in infected mice. These findings suggest that the granuloma or inflammatory cell induced by Schistosoma eggs produced some factors that may be responsible for reduction of these enzymatic activities in the experimental $S$. mansoni.

ALT and AST liver enzymes showed a marked reduction in all groups than the normal control. Otherwise compounds 3, 11 and 12 caused insignificant reduction in ALT activity as compared to normal healthy mice, which in turn may suggest the probability of the protective effect of these compounds in attenuating the cellular damaging effect of bilharzias on the liver tissue. The decrease of liver tissue Transaminases is similar to that reported by Winawer et al., (1965). Zelman and Wang (1959) reported concomitant increase in the serum enzymes that was confirmed by Khan et al. (2001), who stated that, the increased levels of serum ALT and AST enzyme activities may due to the leakage of these enzymes from liver cytosol and mitochondria, respectively which in turn reflected cellular degeneration or destruction occurred in this organ. The observed diminution of AST was more manifested than that of ALT, donating that the later is more specific to the liver, this is due to the fact that AST found in the liver mitochondria in a concentration higher than that of ALT that found in the liver cytosol, yet ALT is less sensitive than AST in detecting liver cell damage, this is in accordance with the reported changes in serum Transaminases in hepatic cirrhosis Wroblewski (1960) and in bilharzial hepatic fibrosis Awadalla et al., (1975).

The present results showed that hepatic total lipids content significantly increased by $S$. mansoni infection meanwhile, eight of the triazine compounds caused an insignificant increase in total lipids content as well as PZQ when compared to normal healthy mice. These results are comparable with that recorded by El-Kharbotly et al. (1965) who found that 
Schistosoma infection caused lipids abnormalities. On the other hand, data on total proteins recorded a significant decrease by $S$. mansoni infection where, a maximum reduction was observed with compound 10. This result is in agreement with Rizk et al. (2006) who found that the total proteins recorded an increase after four weeks of infection then a significant decline after six and eight weeks. In hepatic disease as a result of bilharzial infection, protein anabolism decreases while protein catabolism increases. Also, impairment in protein synthesis was previously reported by Mousa et al., (1975) that mal-absorption may be a contributing factor in decrease of protein synthesis through a defect in absorption of amino acids.

Lipid peroxides were elevated by $S$. mansoni as well as PZQ. Also administration of triazine compounds caused a significant increase. This coincides with Rizk et al. (2006) who found that lipid peroxides were elevated by $S$. mansoni throughout the different durations of infection, and Shaheen et al. (1994) who found that the production of free radicals in the chain of biochemical reactions results in an increase in lipid peroxides. The present results confirmed these finding via elevation of lipid peroxidation products (MDA) that were considered as a marker of lipid membrane damage up on Schistosoma infection and supported by the reduction of liver enzymes via leakage from the liver tissue cells to the blood due to impairment in the membrane permeability and liver fibrosis that should be underlined that reaction end products of lipid peroxides stimulate fibrogenesis Bedossa et al., (1994). Parola et al. (1996) reported that, there are two correlations between collagen deposition and production of MDA and 4hydroxynonemal (HN6) by hepatic cells, these compounds, exert their effects through over expression of fibrogenic cytokines and through the upregulation of procollagen-1 mRNA Casini et al., (1997).

Results on total thiol content revealed a highly significant reduction resulting from oxidative stress due to Schistosomiasis Amaiz et al., (1995). Mice treated with compounds 3, 5, 6, 7, 9, 10 and 11 showed insignificant decrease as well as PZQ, when compared with the normal control. Harlan et al. (1984) reported that liver GSH was drastically depleted in bilharzial infected mice and this depletion is critical as shown by the increased cytotoxicity of $\mathrm{H}_{2} \mathrm{O}_{2}$ in endothelial cells as a result of inhibition of glutathione reductase, which keeps GSH in its reduced state and since total thiol composed of protein thiol and non-protein thiol (GSH). So the reduction in total thiol of the present results equivalent to the reduction in GSH reported by those authors. Also, the infectious diseases associated with decrease of hepatic catalase and GSHPx activities as well as of GSH levels Chomarat et al., (1997), leading to a greater sensitivity to inflammation derived products Sandstorm et al., (1994).

The activity of catalase that revealed a highly significant and progressive reduction was in agreement with Gharib et al. (1999) who showed that, peroxide dismutation yield $\mathrm{H}_{2} \mathrm{O}_{2}$ which is detoxified by catalase resulting in decrease in its activity in bilharzial infected PZQ, 1, 5, 8, 11, 13 and 15 treated groups. While catalase showed a significant increase in its activity in groups $2,3,4,6,7,12,14$ and 16 that indicates the positive effect of these compounds on the bilharzial infection via enhancing the anti-oxidant defense system and improving the catalase enzyme activity .

Sheweita et al. (1998) pointed out that levels of glutathione$S$-transferase were decreased in human and mice infected with Schistosoma mansoni. Moreover, Farrag and Faddah (1998) found that the activity of glutathione- $S$-transferase decreased in S. mansoni infected mice. While Gharib et al. (1999) confirmed that glutathione- $S$-transferase was unaffected in livers of mice infected with $S$. mansoni. Data obtained for
GST activity is in agreement with Gharib et al. (1999), in mice treated with compounds $6,8,9,12,13,14,15$ and 16 while GST enzyme of liver of mice infected with $S$. mansoni only did not show a significant increase when compared with normal. Mice treated with PZQ, (cpd1), (cpd2), (cpd3), (cpd4), (cpd5), (cpd7), (cpd10) and (cpd11) showed a significant increase in GST enzyme activity when compared with the normal that reflects the positive rule of these compounds on GST enzyme activity, i.e., these compounds ameliorate the oxidative stress effect due to $S$. mansoni infection via decreasing the levels of free radicals released, which in turn affect on the GST activity.

The results of the preliminary investigation of the tested sixteen compounds of 1,2, 4-triazine derivatives indicated that mice treated with compound 9 showed a significant reduction of $(27.53 \%)$ in the worm burden. The data also showed that compounds $3,9,10,11,12$ and 13 caused reductions $32.1 \%$, $25.7 \%, 33.2 \%, 25.3 \%, 16.2 \%$ and $22.8 \%$ in the liver eggs count, respectively, as compared with untreated infected mice, but statistical analysis shows that the decrease were insignificant at $\mathrm{P}$-value of 0.05 . This observation indicates that these compounds have a degree of anti-schistosomal activities.

Considerably to Pellegrino et al., (1962) criteria, the present compound 6 showed a reduction in first stage that followed by successful disappearance of immature eggs of the following stages then absence of eggs in the mature stage demonstrating a marked effect on the worm reproductive organs. This result indicates that (cpd6) has a potent antibilharzial effect.

In the present study hematoxyline and eosin stained liver sections from $S$. mansoni infected mice only did not reveal any definitive architectural deformation of the liver, despite the frequency of the number of Schistosoma eggs with their surrounding granulomas reaction in the liver. These results are in agreement with those of Stanger et al. (1967), who found that the liver of $S$. mansoni infected mice did not show any distinct parenchyma abnormalities even after 55 weeks of infection. The most suppressive effect on the development of granulomatous reaction as compared with bilharzial infected liver sections, treatment with (cpd10) had the highest reduction percent of $(99.2 \%)$ and reduced granulomas area Also, inflammatory cell infiltration in liver and around the egg of Schistosoma were not commonly found.

In conclusion, the current study showed that some 1, 2, 4triazine derivatives displayed anti-schistosomal activity. The most effective one was compound 9 as it induced reduction in the worm burden $(27.53 \%)$. The compounds $3,6,7$ and 10 also showed an apparent effect on the granuloma volume.

\section{References}

Amaiz, S. L., Lesury, S., Cutrin, J. C., Boveris, A., 1995. Oxidative stress by acute acetaminophen administration in mouse liver. Free Radic. Biol. Med. 19,303-310.

Andrade, Z. A., Warren, K. S., 1964. Mild prolonged Schistosomiasis in mice. Alternations in host response with time and the development of portal fibrosis. Trans. R. Trop. Med. Hyg. 58(1), 53-57.

Awadalla, H. N., Sherif, A. F., Shafei, A. Z., Khalil, H. A., Gurgis F. K., 1975. Enzyme levels in homogenates of liver from mice infected with $S$. mansoni and from uninfected mice. Int. J. Parasitol. 5(1), 27-31. 
Bancroft, J. D., Stevens, A., 1975. Histopathological stain and their Diagnostic uses. Churchill Livingstone, Edinburgh, London and New York.

Bedossa, P., Houglum, K., Trautwein, C., Holstege, A., Chojkier, M., 1994. Stimulation of collagen 1(I) gene expression is associated with lipid peroxidation in hepatocellular injury. a link to tissue fibrosis? Hepatology. 12, 62-71.

Bonting, S. L., Simon, K. A., Hakins, N. M., 1961. Studies on sodium potassium activated adenosine triphosphatase. I. Quantitative distribution in several tissue of the cat. Arch. Biochem. Biophys. 95, 416-423.

Casini, A., Ceni, E, Salzano, R., Biondi, P., Parola, M., Galli, A., 1997. Neutrophils-derived superoxide anion induces lipid peroxidation and stimulates collagen synthesis in human hepatic stellate cells. role of nitric oxide. Hepatology. 25, 3617.

Cheever, A. W., Duvall, R. H., Hallack, T. A., 1983. Hepatic fibrosis in S. hematobium infected mice. Trans. $R$ Soc. Trop. Med. Hyg. 77, 673-679.

Chomarat, P., Sipowicz, M. A., Diwan, B. A., Fornwald, L. W., Awasthi, Y. C., Anver, M. R., 1997. Distinct time courses of increase in cytochromes P450 1A2, 2A5 and glutathione-S-transferase during the progressive hepatitis associated with Helicobacter hepaticus. Carcinogenesis. 18, 217-990.

Christensen, N. O., Gotsche, G., Frandsen, F., 1984. Parasitological technique for use in routine laboratory maintenance of schistosomes and for use in studies on the epidemiology of human and bovine Schistosomiasis.

El-Aaser, A. A., EL-Merzabani, M. M., 1975. Simultaneous determination of 5-nucleotitase and alkaline phosphatase activities in serum. Z. Klin. Chem. Biochem. 13, 453-459.

El-Kharbotly, M., Shalaby, E. S., Zaki, S. A., Abd ElSalam, R., 1965. Serum lipids in bilharzial hepatic cirrhosis. J. Egypt Med. Assoc. 48, 274.

Falke, D., Rada, B. (1970). Acta Virol. 14, 115.

Farrag, E., Faddah, L. M., 1998. Selenium and vitamin E supplementation provide a good defense mechanism against oxidative stress caused by Schistosoma infection. Bull. Egypt Soc Physiol Sci. 18, 394-405.

Frings, C. S., Fendley, T. V., Dunn, R. T., Queen, C. A., 1972. Improved determination of total serum lipids by sulfophosphovanillin reaction. Clin. Chem. 18, 673.

Gharib, B., Abd-Allah, O. M., Dessein, H., De-Reggi, M., 1999. Development of eosinophils peroxidase activity and concomitant alteration of the antioxidant defenses in the liver of mice infected with Schistosoma mansoni. J. Hepatol. 30, 594-602.

Habig, W. H., Pabst, M. J., Jakoby, W. B., 1974. Glutathione-S-transferase. the first enzymatic step in mercapturic acid formation. J. Biol. Chem. 249, 7130-7139.

Harlan, J. M., Levine, J. D., Callahan, K. S., Schwartz, B. R., Harker, L. A., 1984. Glutathione redox cycle protects cultured endothelial cells against lysis by extracellularly generated hydrogen peroxide. J. Clin. Invest. 73, 706-13.

Hirsch, C., Zouain, C. S., Alves, J. B., Goes, A. M., 1997. Induction of protective immunity in mice using pill, an anion fraction of Schistosoma mansoni adult worm. Parasitol. 115 , $21-28$
Khan, I. A., Reddy, B. V., Mahboob, M., Rahman, M. F., Jamil, E. A., 2001. Effect of phosphorothionate on the reproductive system of male rats . J. Environ. Sci. Health. B36, 445-56 .

Larotski, L. S., Davis, A., 1981. The Schistosomiasis in the world. Bull. World Health Organ. 59, 115-135.

Lowry, O. H., Rosebrough, N. J., Farr, A. L., Randall, R. J., 1951. Protein measurement with the folin phenol reagent. J. Biol. Chem. 193, 265.

Matolcsy, G., 1966. Acta Phytopathol. 1, 245.

Mesbah, L., Soraya, B., Narimane, S., Jean, P. F., 2004. Protective effect of flavonoides against the toxicity of vinblastine cyclophosphamide and paracetamol by inhibition of lipid-peroxydation and increase of liver glutathione. Haematology. 7, 59-67.

Mousa, W., Kheir-Eldin, A. A., El-Sehly, A., Mousa, A. H., 1975. Lipid pattern in bilharzial hepatic fibrosis. Egypt. $J$. Bilh. 2, 83-93.

Parola, M., Leonarduzzi, G., Robino, G., Albano, E., Poli, G., Dianzani, M. U., 1996. On the role of lipid peroxidation in the pathogenesis of liver damage induced by long-standing cholestasis. Free Radic. Biol. Med. 20, 351-9.

Pellegrino, J., Oliveira, C. A., Faria, J., Cunha, A. S., 1962. New approach to the screening of drugs in experimental Schistosomiasis mansoni in mice. Am. J. Trop. Med. Hyg. 11, 201-215

Reitman, S., Frankel, S., 1957. A colorimetric method of determination of serum glutamic oxalacetic and glutamic pyruvic Transaminases. Am. J. Clin. Path. 28, 56.

Rizk, M., Fayed, T. A., Badwy, M., Sabaa-El-Regal, N., 2006. Effect of different durations of Schistosoma mansoni infection on the level of some antioxidants in mice. Med. $J$. world Acad. Sci.16, 25-34.

Saleh, S. (1979). Some biochemical changes in Schistosomiasis mansoni. Egypt J Bilharz. 6, 13-42.

Sandstorm, P. A., Tebbey, P. W., Van Cleave, S., Buttke, T. M., 1994. Lipid hydro peroxides induce apoptosis in $T$ cells displaying a HIV-associated glutathione peroxidase deficiency. J. Biol. Chem. 269, 798-801.

Sedalk, J., Lindsay, R. H., 1968. Estimation of total, proteinbound and non-protein sulfhydryl groups in tissue with Ellman's reagent. Anal. Biochem. 24/25, 192-205.

Shaheen, A. A., Ebeid, A., 1992. Effect of Praziquantel treatment on brain and kidney ATPase activities in healthy and Schistosoma mansoni-infected mice. Arzeimittelforschung. 42, 1504-1506.

Shaheen, A. A., Abd-El-Fattah A. A., Ebeid F. A., 1994. Effects of Praziquantel treatment on lipid peroxide levels and superoxide dismutase activity in tissue of healthy and Schistosoma mansoni infected mice. Arzneimittelforschung. 44, 94-96.

Sheweita, S. A., Mangoura S. A., El-Shemi, A. G., 1998. Different levels of Schistosoma mansoni infection induce change in drug-metabolizing-enzymes. J. Helminthol. 72, 7177.

Stanger, R. J., Warren, K. S., Johnson, E. A., 1967. An electron microscopic study of the liver parenchyma and Schistosome pigment in murine hepatosplenic $S$. mansoni. Am. J. Trop. Med. Hyg. 16, 473-482. 
Swanson, M. A. 1950. Phosphates of the liver. I. Glucose-6phosphatase. J. Biol. Chem. 184, 647.

Tanabe, M., Kaneka, N., Takeuchi, A., 1989. S. mansoni. Suppression of carbamoyl phosphate synthase (ammonia) and ornithine carbamoyl transferase activities in the liver of infected mice. J. Exp. Parasitol. 68, 432-442.

Walters, T. R., Aur, R. J. A., Hernandez, K., Vietti, T. Pinkel, D., 1972. Cancer. 29, 1057.

Warren, K. S. (1972). The immunopathogenesis of Schistosomiasis, a multi-disciplinary approach. Trans. R. Soc. Trop. Med. Hyg. 66, 417-434.

Warren, K. S., 1979. The pathogenesis of hepatosplenic Schistosomiasis from man to monkey to mouse to molecule. In: Prober, H. and Schaffiner, F. (Eds). Progress in liver diseases. NewYork, Grune and Stratton, pp. 439-455.

Winawer, S. J., Broitman, S. A., Cotthieb, L. S., Zamcheck, N., 1965. Serum and liver amylase and transaminase activities in choline deficiency fatty liver and cirrhosis. Gastroenterology. 48, 216-225.

Wroblewski, F., 1960. Serum enzyme alteration in diseases of the liver and biliary tract. Med. Clin. North Am. 44, 699708 .

Xu, J. B., Yuan, X. F., Lang, P. Z., 1997. Determination of catalase activity and catalase inhibition by ultraviolet spectrophotometry. Chinese Environ. Chem. 16, 73-76.

Zelman, S., Wang, C. C., 1959. Transaminases in serum and liver correlated with liver cell necrosis in needle aspiration biopsies. Am. J. Med. Sci. 237, 323-334. 
Table (1): Abbreviation and nomenclature of 1,2,4-triazine derivatives

\begin{tabular}{|l|l|l|}
\hline No. & \multicolumn{1}{c|}{ Names } \\
\hline Cpd1 & & $\begin{array}{l}\text { N-Amino-6-methyl-1,2,4- } \\
\text { triazine 3,5(2H,4H)-dithione }\end{array}$ \\
\hline Cpd2 & & $\begin{array}{l}\text { (Z)-4-Amino-6-methyl-3- } \\
\text { (2-phenylhydrazono)-3,4- } \\
\text { dihydro-1,2,4-triazine-5(2H)- } \\
\text { thione }\end{array}$ \\
\hline Cpd3 &
\end{tabular}




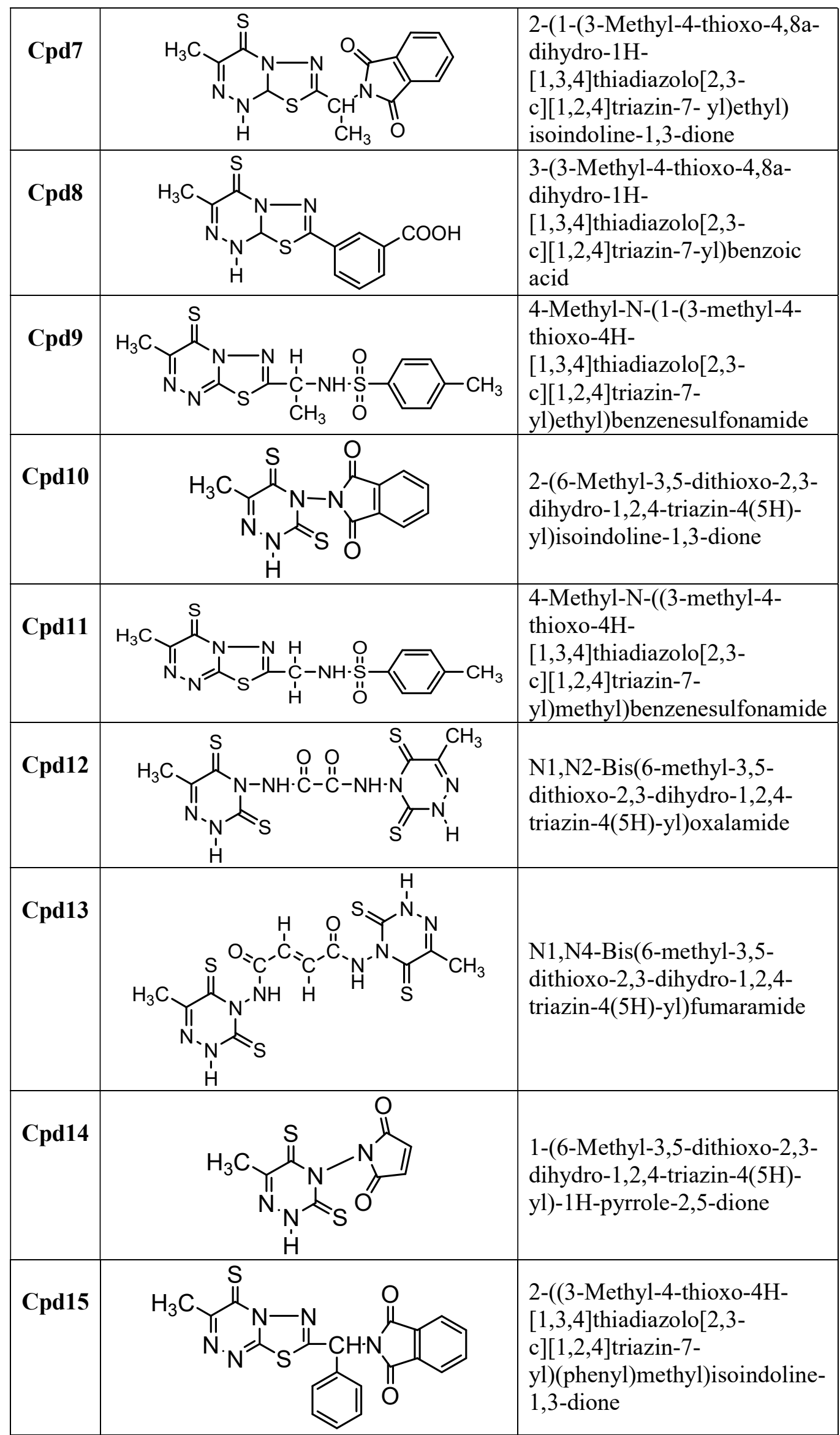




\begin{tabular}{|l|l|l|}
\hline Cpd16 & $\begin{array}{l}\text { 1-(6-Methyl-3,5-dithioxo-2,3- } \\
\text { dihydro-1,2,4-triazin-4(5H)- } \\
\text { yl)pyrrolidine-2,5-dione }\end{array}$ \\
\hline
\end{tabular}

Table (2): The relative liver weight ( $\mathrm{g} / 100 \mathrm{~g}$ body weight) of 6 weeks of post-infection of non-infected animals, bilharzial Praziquantel treated derivatives treated group), $p$ - value <

\begin{tabular}{|c|c|c|}
\hline Groups & $\begin{array}{c}\text { Liver weights } \\
\text { Mean } \pm \text { SD }\end{array}$ & $\begin{array}{c}\text { \% Difference } \\
\text { from normal }\end{array}$ \\
\hline $\begin{array}{c}\text { Non-infected } \\
\text { animals }\end{array}$ & $4.93 \pm 0.22$ & - \\
\hline Infected animals & $7.77 \pm 0.21$ & $57.6^{* *}$ \\
\hline Praziquantel & $6.57 \pm 0.30$ & $33.2^{* *}$ \\
\hline Cpd1 & $8.54 \pm 0.73$ & $73.2^{* *}$ \\
\hline Cpd2 & $7.15 \pm 0.9$ & $45^{* *}$ \\
\hline Cpd3 & $6.59 \pm 0.92$ & $33.6^{* *}$ \\
\hline Cpd4 & $7.88 \pm 0.42$ & $59.8^{* *}$ \\
\hline Cpd5 & $7.24 \pm 0.73$ & $46.8^{* *}$ \\
\hline Cpd6 & $6.86 \pm 0.56$ & $39.1^{* *}$ \\
\hline Cpd7 & $7.14 \pm 0.45$ & $44.8^{* *}$ \\
\hline Cpd8 & $8.05 \pm 1.16$ & $63.2^{* *}$ \\
\hline Cpd9 & $6.72 \pm 0.32$ & $36.3^{* *}$ \\
\hline Cpd10 & $6.73 \pm 0.34$ & $36.5^{* *}$ \\
\hline Cpd11 & $6.66 \pm 0.93$ & $35.09^{* *}$ \\
\hline Cpd12 & $8.15 \pm 0.74$ & $65.3^{* *}$ \\
\hline Cpd13 & $7.83 \pm 0.91$ & $58.8^{* *}$ \\
\hline Cpd14 & $6.86 \pm 0.76$ & $39.1^{* *}$ \\
\hline Cpd15 & $7.61 \pm 0.62$ & $54.3^{* *}$ \\
\hline Cpd16 & $8.58 \pm 1.06$ & $74^{* *}$ \\
\hline
\end{tabular}
infected animals, and 1,2,4 - triazine mice ( 6 mice in each 0.01 . 


\begin{tabular}{|l|c|c|c|c|c|c|} 
Groups & 5'-NT & G-6-P & Na-K & Mg- & ALT & AST \\
\hline
\end{tabular}

Table (3): Activities of liver tissue (5'- NT), (G-6-p), (Na ${ }^{+} \mathrm{K}^{+}$ATPases), ( $\mathrm{Mg}^{2+}$-ATPases) ( $\mu \mathrm{mol}$ $\mathrm{Pi} / \mathrm{min} / \mathrm{g}$ liver), ALT and AST ( $\mu \mathrm{mol}$ pyruvate/min/g liver) 
- $\quad$ Each reading represent mean $\pm \mathrm{SD}$ of $\mathrm{n}$ $=6$.

- The significance of difference from $\mathrm{P}<$ 0.05 to $\mathrm{P}<0.01$ was analyzed by oneway ANOVA and Dunnett test (compare all vs non-infected) using a computer program.

Table (4): Catalase ( $\mathrm{mol} / \mathrm{min} / \mathrm{g}$ liver), GST ( $\mu \mathrm{mol} / \mathrm{min} / \mathrm{g}$ liver), Total Protein content of liver tissue ( $\mathrm{mg} / \mathrm{g}$ liver), Total Lipids (mglg liver), Total Thiol $(\mathrm{mM} / \mathrm{g}$ liver) and MDA content (nmole/g liver)

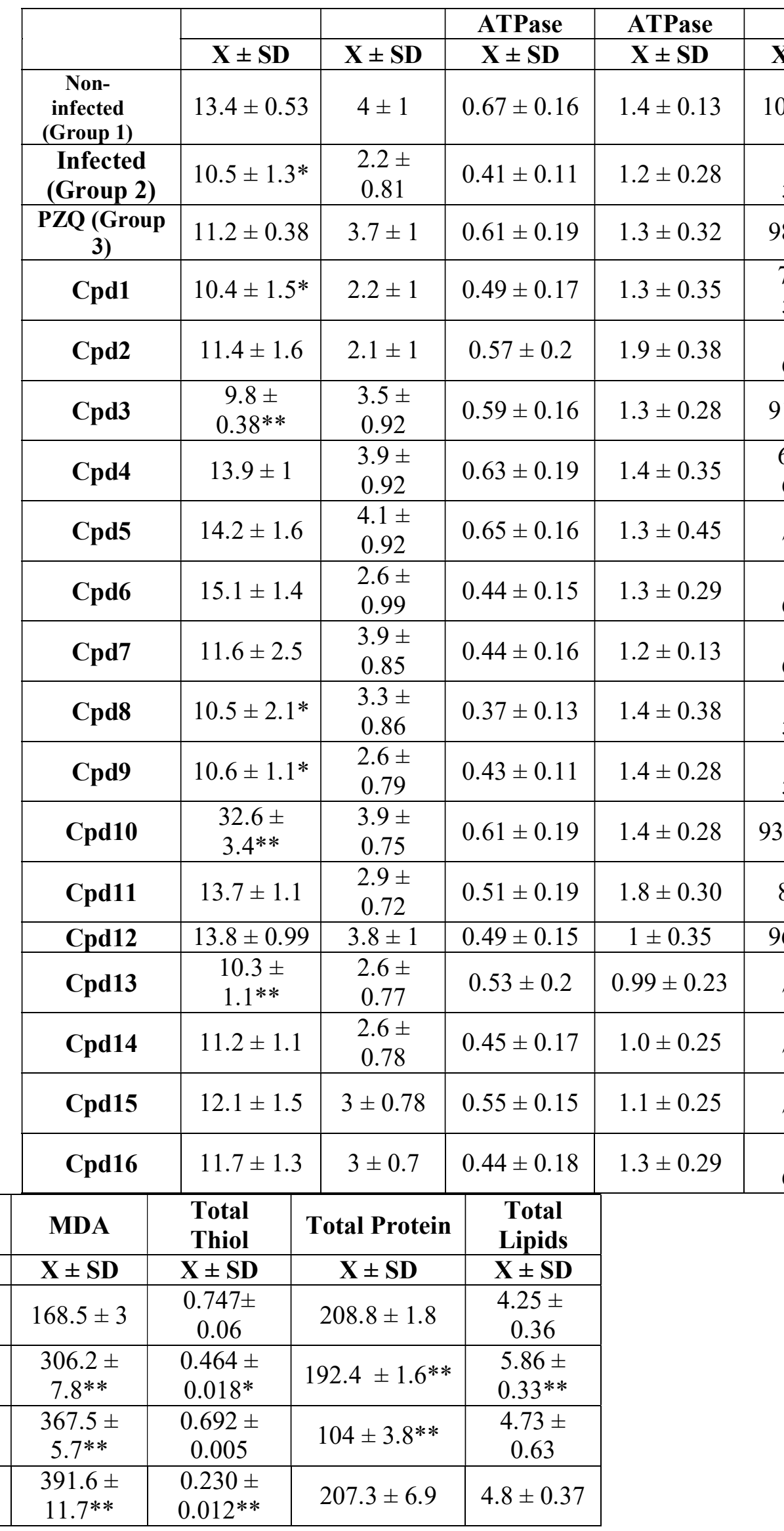




\begin{tabular}{|c|c|c|c|c|c|c|}
\hline Cpd2 & $\begin{array}{c}248.4 \pm \\
39.8^{*}\end{array}$ & $\begin{array}{c}1.96 \pm \\
0.3 * *\end{array}$ & $\begin{array}{c}428.5 \pm \\
9.4^{* *}\end{array}$ & $\begin{array}{l}0.306 \pm \\
0.045^{* *}\end{array}$ & $118 \pm 2.9 * *$ & $4.8 \pm 0.37$ \\
\hline Cpd3 & $\begin{array}{l}361.2 \pm \\
23.2^{* *}\end{array}$ & $\begin{array}{l}1.85 \pm \\
0.29 * *\end{array}$ & $\begin{array}{c}380.5 \pm \\
21^{* *}\end{array}$ & $\begin{array}{c}0.553 \pm \\
0.007\end{array}$ & $187.2 \pm 8.9 * *$ & $\begin{array}{c}4.82 \pm \\
0.63\end{array}$ \\
\hline Cpd4 & $\begin{array}{c}245.6 \pm \\
9.3^{*}\end{array}$ & $\begin{array}{c}2.15 \pm \\
0.4 * *\end{array}$ & $\begin{array}{c}270.4 \pm \\
12.3^{* *}\end{array}$ & $\begin{array}{c}0.466 \\
\pm .012 *\end{array}$ & $112.8 \pm 7.6^{* *}$ & $\begin{array}{l}6.22 \pm \\
0.85 * *\end{array}$ \\
\hline Cpd5 & $\begin{array}{c}100.3 \pm \\
6.9^{* *}\end{array}$ & $\begin{array}{c}1.9 \pm \\
0.18^{* *}\end{array}$ & $\begin{array}{c}219.6 \pm \\
23 * *\end{array}$ & $\begin{array}{c}0.516 \pm \\
0.032\end{array}$ & $128 \pm 2.1^{* *}$ & $\begin{array}{l}5.98 \pm \\
0.45^{* *}\end{array}$ \\
\hline Cpd6 & $\begin{array}{l}300.5 \pm \\
27.6^{* *}\end{array}$ & $\begin{array}{c}1.57 \pm \\
0.22\end{array}$ & $\begin{array}{l}414.5 \pm \\
23.5^{* *}\end{array}$ & $\begin{array}{c}0.512 \pm \\
0.015\end{array}$ & $187.4 \pm 7.5^{* *}$ & $\begin{array}{l}5.19 \pm \\
0.15^{*}\end{array}$ \\
\hline Cpd7 & $\begin{array}{l}288.9 \pm \\
29.0 * * \\
\end{array}$ & $\begin{array}{c}2.2 \pm \\
0.35^{* *}\end{array}$ & $\begin{array}{l}548.8 \pm \\
17.8^{* *}\end{array}$ & $\begin{array}{c}0.613 \pm \\
0.014 \\
\end{array}$ & $181.6 \pm 9.3^{* *}$ & $\begin{array}{l}5.22 \pm \\
0.36^{*} \\
\end{array}$ \\
\hline Cpd8 & $\begin{array}{l}121.3 \pm \\
16.2^{* *}\end{array}$ & $\begin{array}{c}1.06 \pm \\
0.25\end{array}$ & $\begin{array}{l}457.4 \pm \\
23.8^{* *}\end{array}$ & $\begin{array}{l}0.373 \pm \\
0.037 * *\end{array}$ & $194 \pm 3.2^{* *}$ & $\begin{array}{c}.99 \pm \\
0.43\end{array}$ \\
\hline Cpd9 & $\begin{array}{c}228.2 \pm \\
33.7\end{array}$ & $\begin{array}{c}1.38 \pm \\
0.06\end{array}$ & $\begin{array}{c}256.4 \pm \\
9.5^{* *}\end{array}$ & $\begin{array}{c}0.649 \pm \\
0.043\end{array}$ & $139.7 \pm 2.8^{* *}$ & $4.6 \pm 0.33$ \\
\hline Cpd10 & $\begin{array}{c}234.0 \pm \\
16.6\end{array}$ & $\begin{array}{l}4.62 \pm \\
0.44 * *\end{array}$ & $\begin{array}{l}556.7 \pm \\
10.3^{* *}\end{array}$ & $\begin{array}{c}0.542 \pm \\
0.050\end{array}$ & $95.4 \pm 5.4 * *$ & $\begin{array}{l}6.22 \pm \\
0.68 * *\end{array}$ \\
\hline Cpd11 & $\begin{array}{c}153.1 \pm \\
31.4^{*}\end{array}$ & $\begin{array}{l}3.92 \pm \\
0.66^{* *}\end{array}$ & $\begin{array}{c}250.7 \pm \\
8.3^{* *}\end{array}$ & $\begin{array}{c}0.702 \pm \\
0.003\end{array}$ & $143.6 \pm 3.2 * *$ & $\begin{array}{c}4.68 \pm \\
0.41\end{array}$ \\
\hline Cpd12 & $\begin{array}{c}294.7 \pm \\
6.1 * *\end{array}$ & $\begin{array}{c}1.12 \pm \\
0.22\end{array}$ & $\begin{array}{c}648.8 \pm \\
5.2^{* *}\end{array}$ & $\begin{array}{l}0.265 \pm \\
0.013^{* *}\end{array}$ & $160.3 \pm 5.6^{* *}$ & $\begin{array}{l}5.63 \pm \\
0.85^{* *}\end{array}$ \\
\hline Cpd13 & $\begin{array}{c}153.8 \pm \\
30.7^{*} \\
\end{array}$ & $\begin{array}{c}1.25 \pm \\
0.18 \\
\end{array}$ & $\begin{array}{l}439.3 \pm \\
28.5^{* *}\end{array}$ & $\begin{array}{l}0.220 \pm \\
0.026^{* *}\end{array}$ & $194.8 \pm 7.2^{* *}$ & $\begin{array}{l}6.11 \pm \\
0.35^{* *}\end{array}$ \\
\hline Cpd14 & $\begin{array}{l}314.9 \pm \\
29.0^{* *}\end{array}$ & $\begin{array}{c}1.11 \pm \\
0.14\end{array}$ & $\begin{array}{l}448.8 \pm \\
33.9 * *\end{array}$ & $\begin{array}{l}0.185 \pm \\
0.016^{* *}\end{array}$ & $192.8 \pm 6^{* *}$ & $\begin{array}{c}.89 \pm \\
0.47\end{array}$ \\
\hline Cpd15 & $\begin{array}{l}132.9 \pm \\
12.7 * *\end{array}$ & $\begin{array}{c}1.19 \pm \\
0.13\end{array}$ & $\begin{array}{c}510.4 \pm \\
5.3^{* *}\end{array}$ & $\begin{array}{l}0.313 \pm \\
0.001^{* *}\end{array}$ & $190.8 \pm 6.4^{* *}$ & $4.8 \pm 0.45$ \\
\hline Cpd16 & $\begin{array}{c}242.7 \pm \\
28.1\end{array}$ & $1.2 \pm 0.02$ & $\begin{array}{l}381.5 \pm \\
46.8^{* *}\end{array}$ & $\begin{array}{l}0.192 \pm \\
0.002 * *\end{array}$ & $179.6 \pm 5.2 * *$ & $\begin{array}{l}5.62 \pm \\
0.45^{* *}\end{array}$ \\
\hline
\end{tabular}

- $\quad$ Each reading represent mean $\pm \mathrm{SD}$ of $\mathrm{n}=6$.

- The significance of difference from $\mathrm{P}<0.05$ to $\mathrm{P}<0.01$ was analyzed by one-way ANOVA and Dunnett test (compare all vs non-infected) using a computer program.

Table (5): Parasitological data of S. mansoni-infected mice given two doses of 1,2,4-triazine derivatives at the maximum tolerable dose (worm burden and liver eggs count/ $100 \mathrm{~g}$ tissue) $p$-value $<0.05$

\begin{tabular}{|c|c|c|c|c|}
\hline \multirow{2}{*}{ Compounds } & \multicolumn{2}{|c|}{ Worm burden } & \multicolumn{2}{c|}{$\begin{array}{c}\text { Liver eggs count / 100 mg } \\
\text { tissue }\end{array}$} \\
\cline { 2 - 5 } & Mean \pm SD & \multirow{2}{*}{ \%Difference } & \multicolumn{2}{c|}{ Total count } \\
\cline { 4 - 5 } & & Mean \pm SD & $\begin{array}{c}\text { \% } \\
\text { Difference }\end{array}$ \\
\hline $\begin{array}{c}\text { Infected } \\
\text { (Group 2) }\end{array}$ & $38 \pm 12.09$ & - & $1000.1 \pm 566.48$ & - \\
\hline $\begin{array}{c}\text { PZQ (Group } \\
\text { 3) }\end{array}$ & $5.59 \pm 1.39$ & $-85.26^{*}$ & $103.53 \pm 4.83$ & $-89.64^{*}$ \\
\hline Cpd1 & $36.5 \pm 16.78$ & -3.9 & $966.02 \pm 163.49$ & -3.4 \\
\hline
\end{tabular}




\begin{tabular}{|c|c|c|c|c|}
\hline Cpd2 & $41.30 \pm 2.52$ & 8.69 & $1317.13 \pm 85.37$ & 31.7 \\
\hline Cpd3 & $29.67 \pm 9.01$ & -21.9 & $678.69 \pm 113.33$ & -32.1 \\
\hline Cpd4 & $51.40 \pm 5.11$ & $35.26^{*}$ & $1279.85 \pm 71.63$ & 27.97 \\
\hline Cpd5 & $58.74 \pm 2.48$ & $54.58^{*}$ & $1419.27 \pm 53.58$ & 41.91 \\
\hline Cpd6 & $36.69 \pm 16.31$ & -3.4 & $960.45 \pm 140.87$ & -3.9 \\
\hline Cpd7 & $35.17 \pm 6.03$ & -7.4 & $966.17 \pm 102$ & -3.3 \\
\hline Cpd8 & $35.5 \pm 4.12$ & -6.5 & $890.02 \pm 83.31$ & -11 \\
\hline Cpd9 & $27.53 \pm 3.78$ & $-27.53 *$ & $742.2 \pm 370.59$ & -25.7 \\
\hline Cpd10 & $24.94 \pm 10.07$ & -34.3 & $667.54 \pm 98.23$ & -25.38 \\
\hline Cpd11 & $33.41 \pm 2.28$ & -12.07 & $746.23 \pm 49.98$ & -16.2 \\
\hline Cpd12 & $31.6 \pm 8.04$ & -16.8 & $837.6 \pm 377.94$ & -22.8 \\
\hline Cpd13 & $31.1 \pm 10.5$ & -18.1 & $771.3 \pm 345.77$ & 1.8 \\
\hline Cpd14 & $33.3 \pm 8.57$ & -12.3 & $1018.3 \pm 358.06$ & $1389.5 \pm 448.15$ \\
\hline Cpd15 & $31.75 \pm 4.42$ & -16.4 & $1097.8 \pm 377.70$ & 38.9 \\
\hline Cpd16 & $34 \pm 12.82$ & -10.5 & -7.2 & \\
\hline
\end{tabular}


Table (6): Changes in granuloma area of liver sections of S. mansoni-infected mice, PZQ treated mice and infected mice groups after administration of two doses of (Cpd 3, Cpd 6, Cpd 7 and Cpd 10 ) pvalue $<0.05$

\begin{tabular}{|l|l|l|}
\hline Groups & $\begin{array}{l}\text { Granuloma area } \\
\text { Mean } \pm \text { SD } \\
\mathbf{x ~ 1 0 - 3} \mathbf{m m}^{\mathbf{3}}\end{array}$ & \% Difference \\
\hline Infected (Group 2) & $35.18 \pm 7.7$ & - \\
\hline PZQ & $4.09 \pm 1.1^{*}$ & -88.3 \\
\hline Cpd 3 & $0.39 \pm 0.19^{*}$ & -98.8 \\
\hline Cpd 6 & $0.51 \pm 0.20^{*}$ & -98.5 \\
\hline Cpd 7 & $0.84 \pm 0.29 *$ & -97.6 \\
\hline Cpd 10 & $0.26 \pm 0.08^{*}$ & -99.2 \\
\hline
\end{tabular}

Table (7): The percentage of stages of viable egg oogram obtained from the intestinal wall fragments for S. mansoni-infected mice only and infected and treated with PZQ, and AHL10 as follows:-

a) Control Untreated (S. mansoni-infected mice only)

\begin{tabular}{|c|c|c|c|c|c|c|c|}
\hline \multirow[t]{3}{*}{ Mice } & & & & & \multicolumn{2}{|c|}{ Viable Ova } & \multirow[t]{3}{*}{ Shell } \\
\hline & & \multicolumn{3}{|c|}{ Stages of Immature Eggs } & Mature & Total & \\
\hline & $\mathbf{1}_{\mathrm{st}}$ & 2 nd & 3rd & 4th & & & \\
\hline 1 & 23 & 22.6 & 18 & 12.6 & 13.6 & 89.8 & 1.3 \\
\hline 2 & 20.6 & 26 & 17 & 21 & 8 & 92.6 & - \\
\hline 3 & 20.6 & 34.6 & 17.6 & 15.3 & 5.3 & 93.4 & 0.3 \\
\hline 4 & 23.3 & 21.3 & 18.3 & 8.6 & 9.6 & 81.1 & - \\
\hline 5 & 21.6 & 23.3 & 23 & 12.3 & 12.3 & 92.5 & - \\
\hline 6 & 21 & 31.6 & 20 & 10.3 & 12.6 & 95.5 & 0.6 \\
\hline mean & 21.6 & 26.6 & 18.9 & 13.3 & 10.2 & 90.8 & - \\
\hline
\end{tabular}


b) S. mansoni-infected mice and treated with $(P Z Q)$

\begin{tabular}{|c|c|c|c|c|c|c|c|}
\hline \multirow[t]{3}{*}{ Mice } & & & & & \multicolumn{2}{|c|}{ Viable Ova } & \multirow[t]{3}{*}{ Shell } \\
\hline & \multicolumn{4}{|c|}{ Stages of Immature Eggs } & \multirow[t]{2}{*}{ Mature } & \multirow[t]{2}{*}{ Total } & \\
\hline & $\mathbf{1}_{\mathrm{st}}$ & 2 nd & 3rd & 4th & & & \\
\hline 1 & - & - & - & - & - & - & - \\
\hline 2 & - & - & - & - & - & - & 0.33 \\
\hline 3 & - & - & - & - & - & - & - \\
\hline 4 & - & - & - & - & - & - & - \\
\hline 5 & - & - & - & - & - & - & 0.33 \\
\hline 6 & - & - & - & - & - & - & - \\
\hline mean & - & - & - & - & - & - & - \\
\hline
\end{tabular}

c) S. mansoni-infected mice and treated with (AHL10)

\begin{tabular}{|c|c|c|c|c|c|c|c|}
\hline \multirow[t]{3}{*}{ Mice } & & & & & \multicolumn{2}{|c|}{ Viable Ova } & \multirow[t]{3}{*}{ Shell } \\
\hline & \multicolumn{4}{|c|}{ Stages of Immature Eggs } & \multirow[t]{2}{*}{ Mature } & \multirow[t]{2}{*}{ Total } & \\
\hline & $\mathbf{1}_{\text {st }}$ & $2_{\text {nd }}$ & 3rd & $4_{\text {th }}$ & & & \\
\hline 1 & 11.6 & 4 & 3 & 2.3 & 1 & 21.9 & 1.33 \\
\hline 2 & 10 & 9.6 & 3.3 & 4 & 0.3 & 27.2 & 1 \\
\hline 3 & 8 & 7.6 & 4.6 & 0.3 & 1.3 & 21.8 & 1.66 \\
\hline 4 & 10.3 & 10.4 & 5.4 & 1.8 & 0.8 & 28.7 & - \\
\hline 5 & 12.6 & 13.3 & 6.3 & 3.3 & 0.3 & 35 & 7 \\
\hline mean & 10.5 & 8.9 & .54 & 2.3 & - & 26.9 & - \\
\hline
\end{tabular}




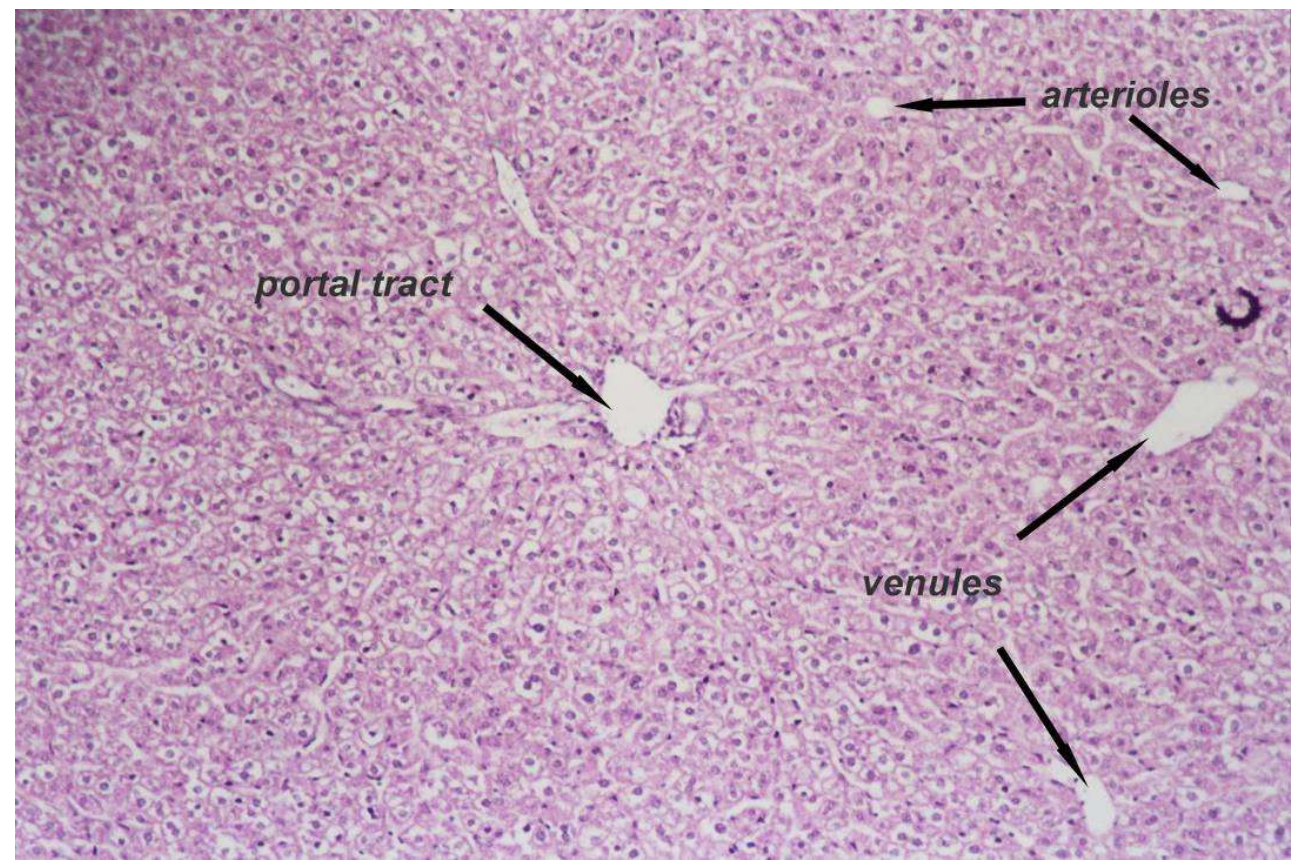

Fig (1a): A photograph of a liver section of control mice showing normal hepatocytes, central vein and portal tract (H\&E stain, 100X).

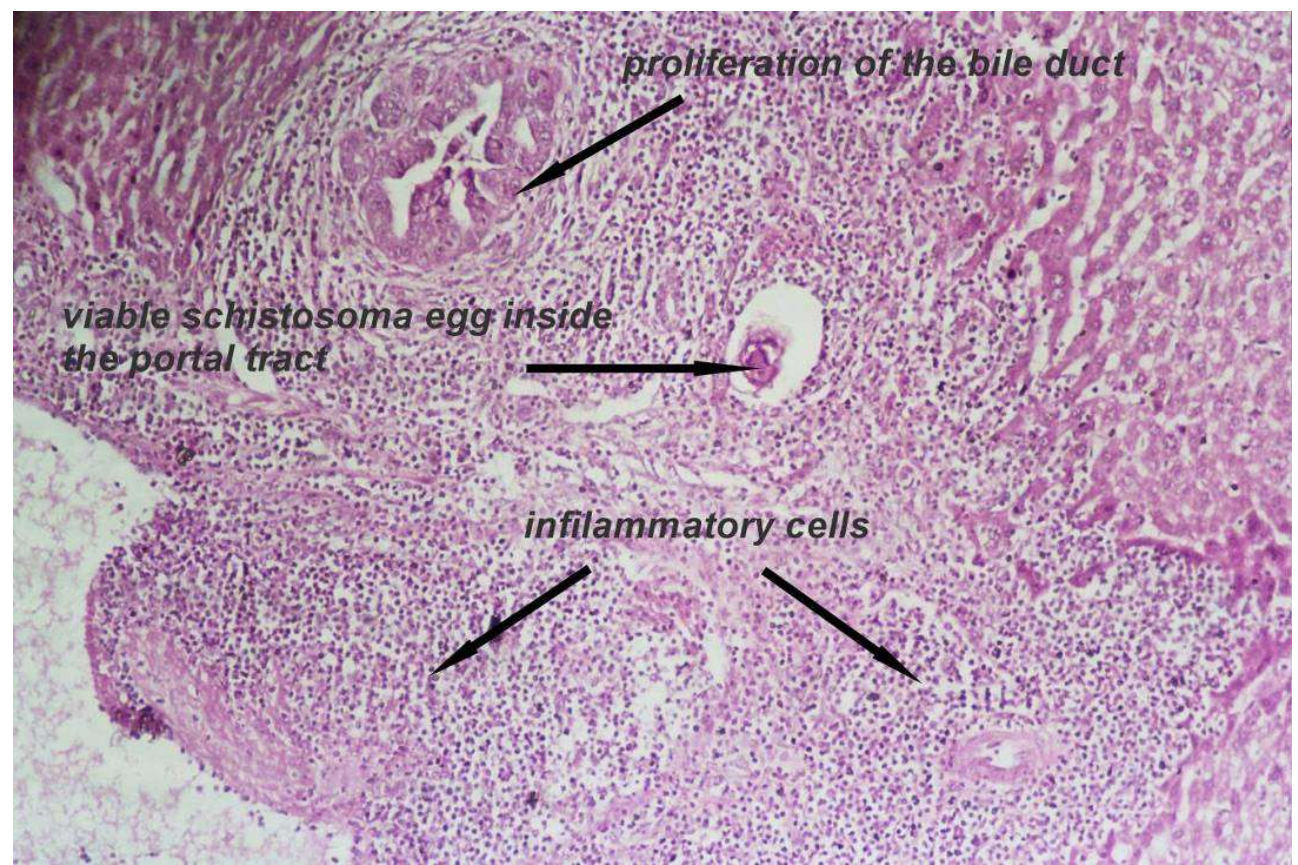

Fig (1b): A photograph of a liver section of $S$. mansoni-infected mice showing the characteristic granulomatous reaction with heavily inflammatory cells surround the egg (H\&E stain, 100X). 


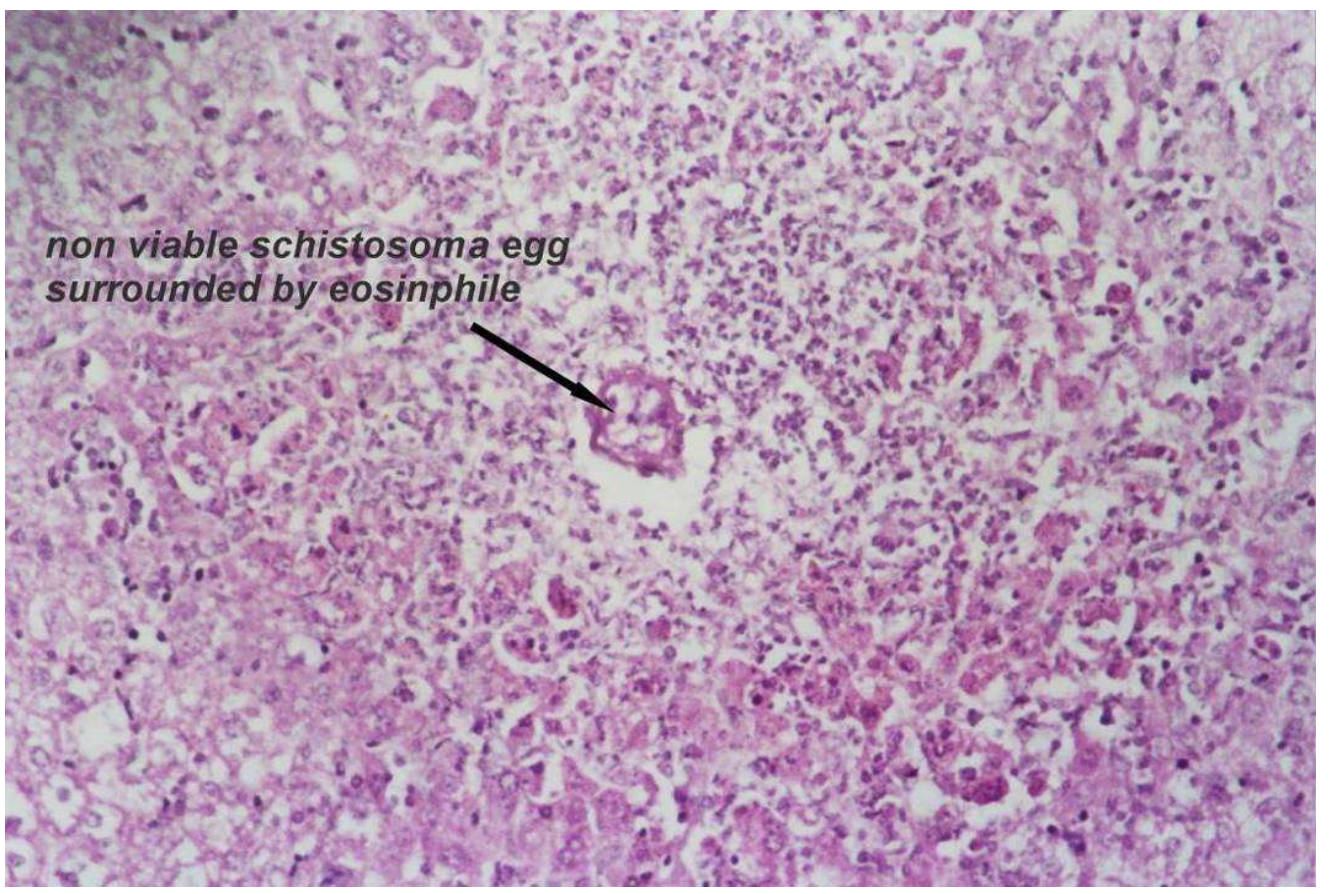

Fig (1c): A photograph of a liver section of $S$. mansoni-infected mice and treated with $(P Z Q)$ showing minimal reduction of (0.92) in the area of granuloma (H\&E stain, 200X).
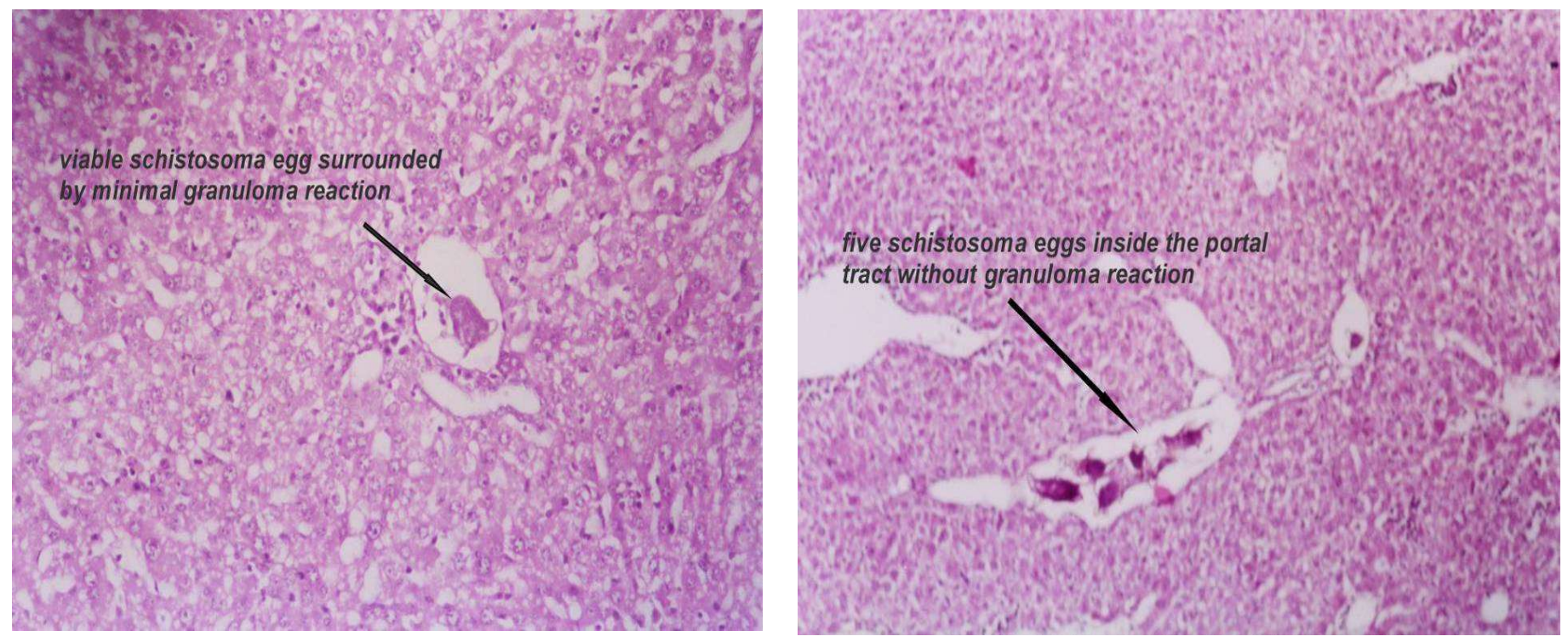

Fig (1d): Different sections from different mice treated with compound 10 showing improvement in the inflammation around egg of $S$. mansoni (H\&E stain, 40X and 100X). 